\title{
CORRESPONDENCE
}

\author{
(To the Editors of the Journal of the Institute of Actuaries)
}

\section{REPORT OF THE WORKING PARTY ON UNIVERSITY TEACHERS' SUPERANNUATION, 1968}

The universities are at present considering the question of superannuation in the light of the report of the working party and the other printed material that has been produced. Because of this, the note by Mr C. A. Poyser (J.I.A.94, 385) calls, I feel, for some comment.

For a balanced survey of the whole subject, I know of nothing better than the notes by Mr E. P. Weller, the late Chairman of the Central Council, who was himself a member of the working party. The object of the notes was to fill in the background to the report of the working party with a view to helping others to make an informed comparison between the Federated Superannuation Scheme for Universities (FSSU) and a terminal salary scheme. He stated, 'I am only concerned that the decision between the two schemes should be made with the fullest possible understanding of what is involved'. The notes were published in a pamphlet by the FSSU Secretariat.

I had a great personal regard for Mr E. P. Weller, who had a deep knowledge of the FSSU both from his position at the centre of the organisation and from his practical experience in operating the FSSU on behalf of his College. His wide experience gave him a deep understanding of all problems relating to pensions. The notes were very much his own work, though he did, of course, consult others and, in particular, I had the opportunity of commenting on some matters where he wanted to confirm the correctness of his statements. For brevity in what follows I refer to his notes simply as 'Weller, para.'

The note by Mr Poyser (p. 386, line 28) suggests that the figures for possible FSSU benefits compared with the alternative terminal salary scheme conflict with the current experience as regards supplementation. Mr Poyser has, however, given a substantial reason for the apparent conflict in the second sentence of his paragraph. Past experience with regard to salaries is discussed in Weller, paras. 17 to 19 , which put the matter in perspective.

The cost of supplementation is affected by other factors than the inflation of terminal salaries in relation to total contributions and policy benefits-see Weller, para. 20. In particular, eligible service for supplementation may include periods in respect of which no FSSU benefits accrued.

Weller's notes put in a different, clearer light the prospects for new entrants (paras. 23 to 25 ), the assumptions underlying the figures (appendix to the notes), the similarity of supplementation under the FSSU and the emerging cost under a terminal salary scheme (paras. 26 and 27) and so on.

The note by Mr Poyser (p. 387, line 40) suggests that a more meaningful comparison would have been made if the calculations had assumed a rate of interest nearer to that likely to be earned by insurance companies and had allowed for changes in salary levels. If the statements about the two sets of assumptions in paras. 131 and 143 of the report are put side by side, it appears that comparable assumptions have been made. The explanation why the surrender value is put at a lower figure than the value of the paid-up benefits is that the latter includes the value placed upon future bonuses, as might be 
expected from the nature of the calculation, not (as Mr Poyser appears to think) because they have been valued at too low a rate of interest.

For a balanced summary of the pros and cons of FSSU as compared with a possible terminal salary scheme, Weller, para. 50 can scarcely be bettered.

30 May 1969

\section{Yours faithfully,}

M. E. OGBORN. 